Rev. Int. Contam. Ambie. 33 (4) 713-717, 2017

DOI: 10.20937/RICA.2017.33.04.14

SHORT COMMUNICATION

\title{
GONADAL HISTOPATHOLOGY OF FISH FROM LA PÓLVORA URBAN LAGOON IN THE GRIJALVA BASIN, MEXICO
}

\author{
Aarón TORRES-MARTÍNEZ*, Alberto J. SÁNCHEZ, Nicolás ALVÁREZ-PLIEGO, \\ Arlette Amalia HERNÁNDEZ-FRANYUTTI, Juan Carlos LÓPEZ-HERNÁNDEZ and \\ Jesús BAUTISTA-REGIL
}

División Académica de Ciencias Biológicas, Universidad Juárez Autónoma de Tabasco. Carretera VillahermosaCárdenas, kilómetro 0.5, Entronque a Bosques de Saloya, Villahermosa, Tabasco, México, C. P. 86039

*Corresponding author: torresmartinezar@hotmail.com

(Received April 2016; accepted March 2017)

Key words: aquatic pollution, reproductive toxicology, ovary, testis, ichthyofauna

\begin{abstract}
Studies on environmental pollution in Mexican freshwater ecosystems by means of fish histopathology are extremely scarce. In that view, this research analyzed the gonad histopathology of four teleost fish species from a hyper-eutrophicated fragmented urban lagoon, in order to determine possible harmful effects of water pollutants on their reproductive fitness. Gonads were processed by histological conventional techniques. The gonadal alterations detected in both, the clupeid Dorosoma petenense and the cichlid Thorichthys meeki expose the need to clarify the connection of these alterations to the presence of specific pollutants.
\end{abstract}

Palabras clave: contaminación acuática, toxicología reproductiva, ovario, testículo, ictiofauna

\section{RESUMEN}

El diagnóstico ambiental de los ecosistemas dulceacuícolas a través de la histopatología de los peces ha sido poco abordado en México. Con base en lo anterior se realizó un análisis histopatológico de las gónadas de cuatro especies de teleósteos provenientes de una laguna urbana hipertrófica y fragmentada, con la finalidad de identificar posibles alteraciones reproductivas inducidas por contaminantes presentes en el agua. Las gónadas se procesaron con técnicas histológicas de rutina. Las alteraciones histopatológicas detectadas en las gónadas de Dorosoma petenense y Thorichthys meeki exponen la necesidad de establecer una conexión directa entre estas alteraciones con la presencia de contaminantes específicos.

\section{INTRODUCTION}

Environmental pollution has become such a serious problem, that as Plath et al. (2015) stated: More and more aquatic habitats are currently becoming extreme to fishes due to novel stressors stemming from human activities. These stressors can potentially impair, in different ways, the sustainability of aquatic 
ecosystems. Particularly, several xenobiotics present in urban wastewaters dumped into limnetic ecosystems have shown to impair fish reproductive behavior, physiology, and morphology. Fragmentation of urban lagoons can accelerate ecological impairment through the exponential accumulation of pollutants in water and the isolation of fish populations in a limited area. Moreover, highly volatile estrogenic compounds can be transported in the atmosphere from remote sites, without any hydraulic connection among sites (Schwaiger et al. 1997). All of this has caused an increasing interest in evaluating the current health status of urban aquatic ecosystems, aiming to drive restoration and conservation strategies (e.g. Dunalska et al. 2015). Fish are particularly useful for environmental impact assessment studies because of their over-sensitiveness for incorporating pollutants both directly from water and indirectly through the trophic web (Magar and Bias 2013). Many of these compounds can directly disrupt various physiological processes, even in very low concentrations; meanwhile others indirectly act through changes in physicochemical properties of water (Steinhagen et al. 1989). Previous studies have shown that xenobiotic compounds can inhibit immunological responses in fish at different levels, increasing their vulnerability to infectious diseases (Dunier 1996). On the other hand, some studies have reported an increase of fish's immune response from polluted ecosystems exposed to heavy metals in water (Schwaiger et al. 1997). Chronic exposure to certain xenobiotics cause reproductive abnormalities in different fish species and this can be evaluated by means of biomarkers of environmental stress. Among these, histopathology of several organs has proven to be a useful tool for xenobiotic identification in marine and freshwater environments (Louiz et al. 2009). Gonadal histopathology is particularly important because it allows identifying alterations in the reproductive fitness of a given species and so determining their risk status in habitat (Feist et al. 2015). On that basis, this research analyzed the histopathology of four fish species inhabiting at the urban lagoon La Pólvora; the cichlids Thorichthys helleri and Thorichthys meeki, the clupeid Dorosoma petenense and the non-native loricariid Pterygoplichthys spp., which may show different sensitivities to aquatic pollution, as it has been documented in several teleost species inhabiting polluted environments (Norey et al. 1990). Given that La Pólvora urban lagoon is a reservoir with high levels of organic pollution (Sánchez et al. 2012), the aim of this study was to determine the presence of histopathological alterations in gonads of these four fish species.

\section{MATERIALS AND METHODS}

\section{Study area}

La Pólvora ( $17^{\circ} 58^{\prime} 56^{\prime \prime}-17^{\circ} 58^{\prime} 45^{\prime \prime} \mathrm{N} ; 92^{\circ} 55^{\prime} 30^{\prime \prime}$ $-92^{\circ} 55^{\prime} 31^{\prime \prime} \mathrm{O}$ ) is located in Villahermosa city, $2 \mathrm{~m}$ above sea level in the Grijalva basin. This reservoir's interconnection was lost since 1984, so it has only received water from the Grijalva river during the extreme floods in 2007 and 2008. Currently, La Pólvora is a hyper-eutrophic polluted lagoon with high levels of fecal coliforms, absence of crustaceans and low fish diversity.

\section{Fish sampling}

Fish were caught during the day using a casting net, in April 2015. All organisms used in this study were sexually mature. Specimens were transported to the laboratory in thermal containers with artificial oxygenation. All procedures on fish were conducted according to the international standards of animal welfare (Canadian Council on Animal Care 2005).

\section{Histopathology}

Specimens were euthanized with an anesthetic overdose. Tissues were processed for histopathological examination as described by Humason (1979). Gonads were dissected and quickly fixed in Bouin's fixative (formaldehyde, picric acid and acetic acid) during 24 hours and dehydrated in graded ethanol solutions (10, $30,50,70,80,96$ y 99\%, 30 minutes in each concentration). Afterwards, gonads were cleared in xylene during 60 minutes and embedded in paraffin with an inclusor Riechert-Jung ${ }^{\circledR}$. Gonads were serially sectioned at $7 \mu \mathrm{m}$ section thickness in a rotary microtome Thermo Scientific Micron HM325®, and stained with hematoxylin and eosin (H-E) (general panorama, nuclei, cell boundaries and acidophilia). Histological preparations were analyzed with an optic microscope Carl Zeiss model Axiostar ${ }^{\circledR}$ using the morphometric software ZEM ${ }^{\circledR}$ 2011. Micrographs were taken with a Carl Zeiss AxioCam ${ }^{\circledR}$ digital camera. Histological material was deposited in the histological collection of the Laboratorio de Acuicultura Tropical, División Académica de Ciencias Biológicas, Universidad Juárez Autónoma de Tabasco.

\section{RESULTS AND DISCUSSION}

A total of thirty-one specimens were collected at La Pólvora; Dorosoma petenense (12), Thorichthys meeki (10), Thorichthys helleri (4), and Pterygoplichthys spp. (5). Histopathology has been recognized as 
a sensitive tool to identify tissue alterations induced by various water pollutants (Stentiford et al. 2014). In this study, the most severe histopathological alteration was observed in the testes of $D$. petenense, which showed generalized testicular degeneration (Fig. 1) and disintegration of seminiferous lobules, due to fragmentation of basement membrane. In Cichlasoma dimerus this condition was attributed to endosulfan exposure, a common fertilizer used in agriculture (Da Cuña et al. 2013). In gonads of $D$. petenense and T. meeki just some melanomacrophage centers (MMCs) were observed in the interstitial compartment (images not shown) as groupings of macrophages containing intracellular pigments such as melanin, lipofuscin, and hemosiderin, as it has been reported in other fish species (Agius and Roberts 2003). MMCs have been used as environmental stress biomarkers in several teleost species, given that their presence is considered an immunological response to numerous contaminants and pathogens (Blazer 2002). The low presence of MMCs in $D$. petenense and T. meeki could be interpreted as absence of environmental stressors. However, in view of the recurrence of other serious histopathological abnormalities in these organisms, it may be toxic compounds at La Pólvora negatively modulating the immune system and increasing the vulnerability of these species to disease (Bols et al. 2001). In fact, an intense and generalized immunological reaction of acidophilic cells was only observed in one specimen of $D$. petenense (image not shown).

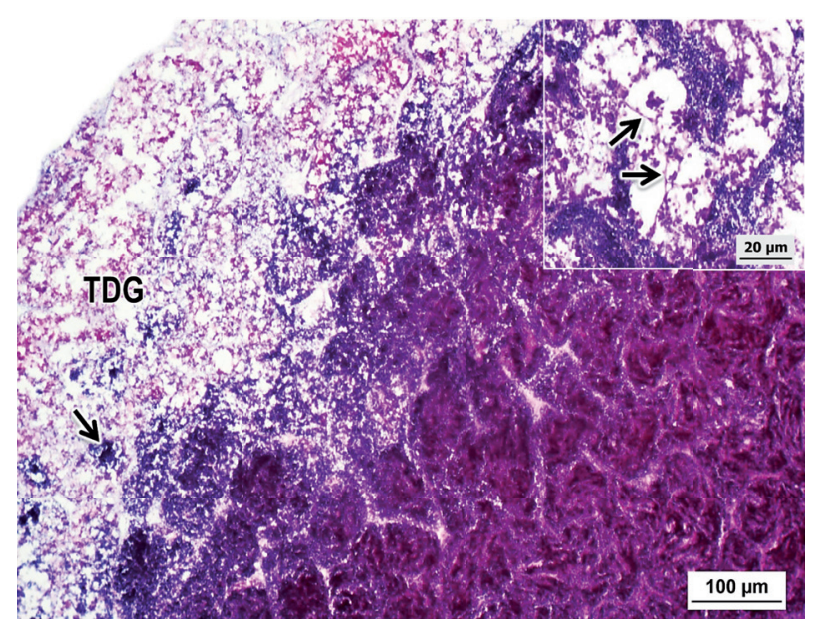

Fig. 1. Testis degeneration in the clupeid Dorosoma petenense. Generalized tissue degeneration (TDG) produced by detachment and fragmentation of basement membrane (arrows, inset) delimiting seminiferous lobules. The scattered nuclei from spermatozoa are showed (arrow), $100 \mathrm{X}$
Particularly, frequent protozoan infections observed in testes of D. petenense and T. meeki (Fig. 2) support the hypothesis of immunological impairment, because parasitic diseases are related to the increase of organic concentrations and temperatures in polluted waters (Anderson 1990), a condition determined in La Pólvora by Sánchez et al. (2012). Notably, females did not show parasitic infection in ovaries, suggesting that this pathological condition is also influenced by the sex of the host. However, the most common alterations in ovaries of $D$. petenense were follicular epithelium expansion, fracture of follicular basement membrane (Fig. 3), follicular atresia, and interstitial proteinaceous fluid accumulation (IPF) (Fig. 4). In all species included in this study, follicular atresia consisted of progressive degeneration of the follicular structure. Atretic follicles of $D$. petenense showed oocyte cytoplasmic vacuolization, fracture of the zona pellucida as well as follicular epithelium hypertrophy. Although atresia is a normal degenerative process influenced by the fertility index of each species (Uribe-Aranzábal et al. 2006), its rate may be influenced by a range of pollutants such as organochlorine pesticides, malathion, petroleum compounds, and aromatic hydrocarbons (Mlambo et al. 2009, Bols et al. 2001), as well as ecological disturbances that generate stress in female fish (Overstreet 1988). Despite follicular atresia was regularly

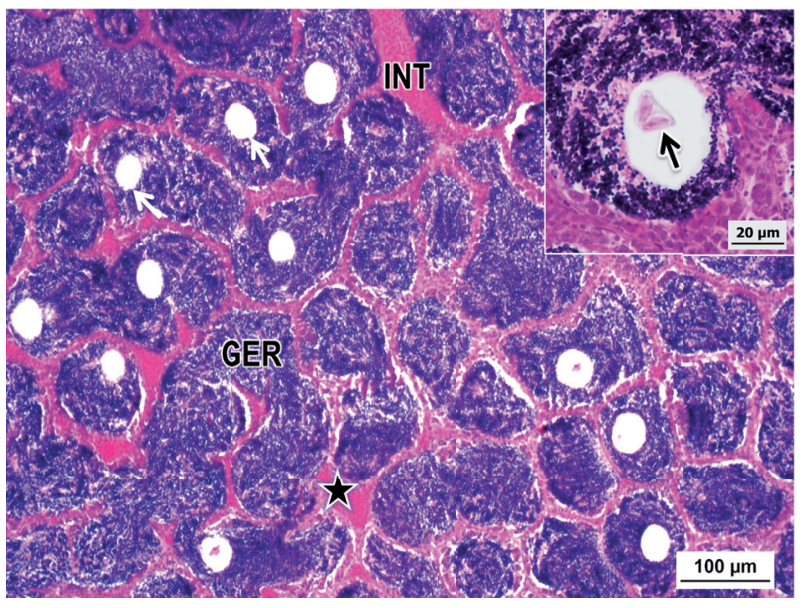

Fig. 2. Testis alterations induced by pathogenic infection in the cichlid Thorichthys meeki. Interstitial (INT) and germinal compartment (GER), the latter saturated with spermatozoa inside seminiferous lobules (blue). Testicular parenchyma presents numerous orifices caused by parasitic infection (arrow), 100X. Infection is also accompanied by vascular hypertrophy of the interstitial compartment (star). The pathogenic agents, protozoa, are clearly observed into a seminiferous lobule (inset), $400 \mathrm{X}$ 


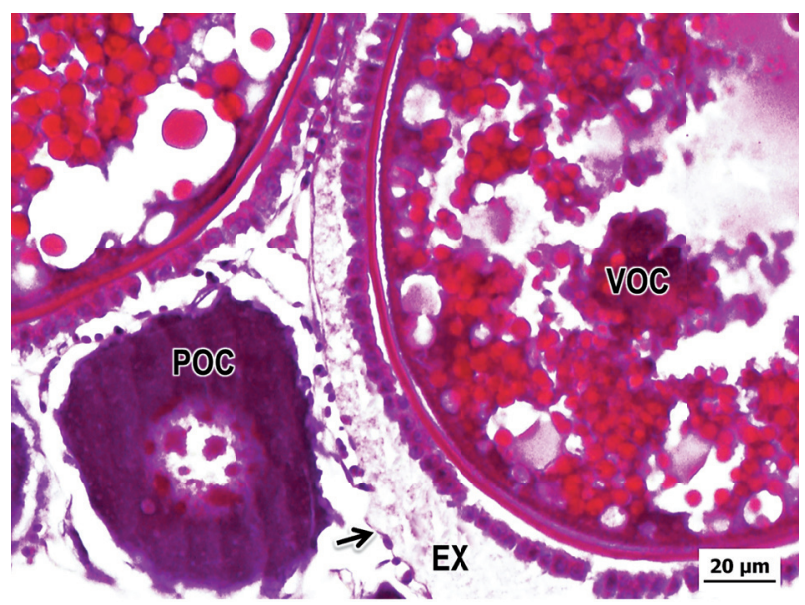

Fig. 3. Expansion of the follicular epithelium in vitellogenic oocytes of Dorosoma petenense. In some vitellogenic oocytes (VOC) the follicular epithelium is expanded due to accumulation of intracellular fluid (EX), causing rupture of basement membrane (arrow) and structural deterioration of follicles. A previtellogenic oocyte (POC) with follicular epithelium detachment is also observed, $400 \mathrm{X}$

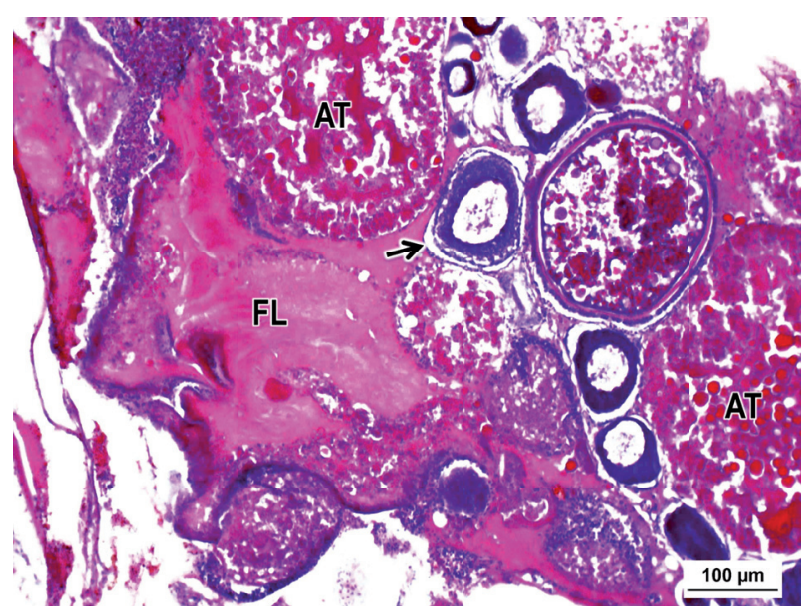

Fig. 4. Ovarian alterations in Dorosoma petenense. Intersticial proteinaceus fluid (FL) surrounding previtellogenic and vitellogenic oocytes with ooplasmic retraction and detachment of follicular epithelium (arrows). Atretic vitellogenic oocytes with cytoplasmic vacuolization, hypertrophied follicular epithelium, and zona pellucida fragmentation, $100 \mathrm{X}$

observed in all of fish considered herein, its recurrence was highest in $D$. petenense, according with a generalized destruction of ovarian tissues. The IPF presence in the ovarian stroma of $D$. petenense was also documented in the fathead minnow Pimephales promelas and attributed to estrogenic compounds exposure, which may induce extracellular accumulation of vitellogenins (USEPA 2006). However, in the tilapia Oreochromis mossambicus and zebrafish $D a$ - nio rerio FPI presence was attributed to vitellogenic oocyte degeneration induced by chemical exposure (Mlambo et al. 2009, van der Ven et al. 2003). In this study, gonadal histopathological alterations in T. helleri and Pterygoplichthy spp. were absent, but this does not exclude them of disruptions at other biological organization levels. In fact, sensitiveness variations of physiological systems facing environmental stressors should be an essential topic in biomonitoring programs, because xenobiotics harm fish populations first at molecular, biochemical, and cellular levels. Only when physiological mechanisms cannot restore homeostatic balance, pathological effects appear in higher levels of biological complexity as morphology and behavior (Rice et al. 1996). Based on this, possible alterations may occur in most basal levels of biological organization of fish from La Pólvora, but complementary studies will be necessary to test this hypothesis and establish a clear connection between pathological alterations and the presence of specific pollutants in urban waters.

\section{REFERENCES}

Agius C. and Roberts J. (2003). Melano-macrophague centres and their role in fish pathology. J. Fish. Dis. 26 (9), 499-509.

DOI: $10.1046 / j .1365-2761.2003 .00485 . x$

Anderson D.P. (1990). Immunological indicators: effects of environmental stress on immune protection and disease outbreaks. American Fisheries Society 8, 38-50.

Blazer V.S. (2002). Histopathological assessment of gonadal tissue in wild fishes. Fish. Physiol. Biochem. 26 (1), 85-101. DOI: 10.1023/A:1023332216713

Bols N.C., Brubacher J.L., Ganassin R.C. and Lee L.E.J. (2001). Ecotoxicology and innate immunity in fish. Dev. Comp. Immunol. 25 (8-9), 853-873.

DOI: $10.1016 / \mathrm{S} 0145-305 \mathrm{X}(01) 00040-4$

Canadian Councial on Animal Care (2005). Care and the use of fish in research, teaching and testing [online]. http://ccac.ca/Documents/Standards/Guidelines/Fish. pdf $21 / 02 / 2016$

Da Cuña R.H., Pandolfi M., Genovese G., Piazza Y., Ansaldo M. and Lo Nostro F. (2013). Endocrine disruptive potential of endosulfan on the reproductive axis of Cichlasoma dimerus, (Perciformes, Cichlidae). Sci. Total. Environ. 126, 299-305.

DOI: 10.1016/j.aquatox.2012.09.015

Dunalska J., Grochowska J., Wiśniewski G. and Napiórkowska-Krzebietke A. (2015). Can we restore badly degraded urban lakes? Ecol. Eng. 82, 432-441. DOI: $10.1016 /$ j.ecoleng.2015.05.037 
Dunier M. (1996). Water pollution and inmmunosuppression of freshwater fish. Ital. J. Zool. 63 (4), 303-309. DOI: $10.1080 / 11250009609356150$

Feist S.W., Stentiford G.D., Kent M.L., Ribeiro-Santos A. and Lorence P. (2015). Histopathological assessment of liver and gonad pathology in continental slope fish from the northeast Atlantic Ocean. Mar. Environ. Res.106, 42-50. DOI: 10.1016/j.marenvres.2015.02.004

Humason G.L. (1979). Animal tissue techniques. Freeman Company. San Francisco, USA, 661 pp.

Louiz I., Ben-Attia M. and Ben-Hassine O.K. (2009). Gonadosomatic index and gonad histopathology of Gobiusniger (Gobiidae, Teleost) from Bizerta lagoon (Tunisia): evidence of reproductive disturbance. Fish. Res.100 (3), 266-273.

DOI: 10.1016/j.fishres.2009.08.009

Magar R.S. and Bias U.E. (2013). Histopathological impact of Malation in the ovary of the freshwater fish Channa punctatus. Int. Res. J. Environment. Sci. 2 (3), 59-61.

Mlambo S.S., van Vuren J.H.J., Barnhoorn I.E.J. and Bornman M.S. (2009). Histopathological changes in the reproductive system (ovaries and testis) of Oreochromis mossambicus following exposure to DDT. Environ.Toxicol. Phar. 28 (1), 133-139.

DOI: $10.1016 /$ j.etap.2009.03.011

Norey C.G., Cryer A. and Kay J. (1990). A comparison of cadmium-induced methallotionein gene expression and $\mathrm{M} 2+$ distribution in the tissues of cadmium- sensitive (rainbow trout: Salmo gaidneri) and tolerant (stone loach: Noemacheilus barbatulus) species of freshwater fish. Comp. Biochem. Phys. 97 (2), 221-225.

DOI: 10.1016/0742-8413(90)90131-R

Overstreet R.M. (1988). Aquatic pollution problems, Southeastern U.S. coasts: histopathological indicators. Aquat. Toxicol. 11 (3-4), 213-239.

DOI: $10.1016 / 0166-445 X(88) 90076-8$

Plath M., Tobler M. and Riesch R. (2015). Extremophile fishes: An introduction. In: Extremophile fishes. Ecology, evolution, and physiology of teleosts in extreme environments (R. Riesch, M. Tobler and M. Plath, Eds.). Springer, Switzerland, pp. 1-7.
Rice C.D., Kergosien D.H. and Adams S.M. (1996). Innate immune function as a bioindicator of pollution stress in fish. Ecotox. Environ. Safe. 33 (2), 186-192. DOI: 10.1006/eesa.1996.0024

Sánchez A.J., Salcedo M.A., Macossay-Cortéz A.A., Feria-Díaz Y., Vázquez L., Ovando N. and Rosado L. (2012). Calidad ambiental de la laguna urbana La Pólvora en la cuenca del río Grijalva. Tecnol. Cienc. Agua 3, 143-152.

Schwaiger J., Wanke R., Adam S., Pawert M., Honnan W. and Triebskorn R. (1997). The use of histopathological indicators to evaluate contaminant-related stress in fish. J. Aquat. Toxicol. 6 (1), 75-86.

DOI: 10.1023/A:1008212000208

Steinhagen D., Kruse P. and Korting W. (1989). Effects of immunosuppressive agents on common carp infected with the haemoflagellateTrypanoplasma borrely. Dis. Aquat. Org. 7, 67-69. DOI: 10.3354/dao007067

Stentiford G.D., Massoud M.S., Al-Mudhhi S., Al-Sarawi M.A., Al-Enezi M. and Lyons B.P. (2014). Histopathological survey of potential biomarkers for the assessment of contaminant related biological effects in species of fish and shellfish collected from Kuwait Bay, Arabian Gulf. Mar. Environ. Res. 98, 60-67. DOI: 10.1016/j.marenvres.2014.03.005

Uribe-Aranzábal M.C., de la Rosa-Cruz G., GarcíaAlarcón A., Guerrero-Estévez S.M. and

Aguilar-Morales M. (2006). Características histológicas de los estadios de atresia de folículos ováricos en dos especies de teleósteos vivíparos:Ilyodon whitei (Meek, 1904) y Goodea atripinnis (Jordan, 1880) (Goodeidae). Hidrobiologica 16 (1), 67-73.

USEPA (2006). EPA-816-K-02-018. Histopathology guidelines for the Fathead Minnow (Pimephales promelas) 21-day reproduction assay. Guideline. United States Environmental Protection Agency. Washington, D.C., USA, 53 pp.

van der Ven L.T.M., Wester P.W. and Vost J.G. (2003). Histopathology as a tool for the evaluation of endocrine disruption in zebrafish (Danio rerio). Environ. Toxicol. Chem. 22 (4), 908-913. DOI: 10.1002/etc.5620220431 